\title{
EFFECTS OF EXHAUSTIVE EXERCISE AND CONTUSION ON AUTOPHAGY-RELATED FACTORS IN SKELETAL MUSCLE OF RATS
}

\author{
EFEITOS DE EXERCÍCIO EXAUSTIVO E DE CONTUSÕES SOBRE FATORES RELACIONADOS COM AUTOFAGIA \\ NOMÚSCULOESQUELÉTICODERATOS
}

\author{
EFECTOS DEL EJERCICIO EXHAUSTIVO Y DE CONTUSIÓN SOBREFACTORES RELACIONADOS A LA \\ AUTOFAGIA EN EL MÚSCULOESQUELÉTICODERATONES
}

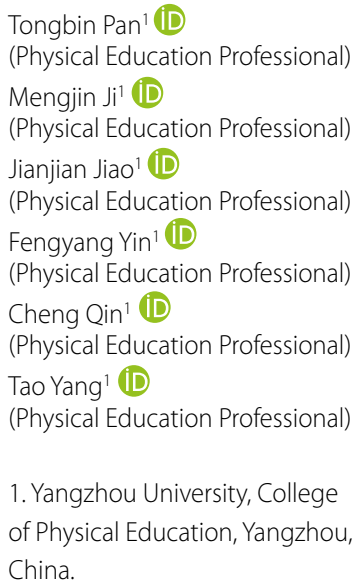

\section{Correspondence}

Pan Tongbin

College of Physical Education, YangZhou University, Yangzhou City, Jiangsu Province, China. 225009. panlichina@sina.com

\begin{abstract}
Objective: To study the effects of exhaustive exercise and contusion on autophagy-related factors Beclin1, LC3 and PINK1 expression in the skeletal muscle of rats. Methods: Forty-two male SD rats were randomly divided into 7 groups, 6 rats in each group: C, D0, D24, D48, E0, E24, and E48. Each group of rats was killed and dissected at the different respective time points specified above. The whole quadriceps femoris of the left hind limbs were removed and divided into two parts, one for mRNAs of Beclin1, LC3 and PINK1 by real-time fluorescent quantitative $P C R$, and the other for LC3 protein by Western blotting. Results: Compared with group $C$, the contents of Beclin 1 mRNA, PINK1 mRNA, and LC3 mRNA in the immediate exhaustive exercise group (E0) were significantly reduced $p<0.01$. However, the levels of PINK1 mRNA, LC3 mRNA, and LC3 protein in skeletal muscle cells increased significantly in the 48 hours after exhaustion (E48) $p<0.05$, suggesting that cell autophagy had an increasing trend during the recovery period. Meanwhile, compared with the C group, the contents of Beclin 1 mRNA, PINK1 mRNA, and LC3 mRNA in the immediate blunt contusion group (D0) increased significantly $p<0.01$ and were followed by a downward trend. Conclusion: Generally, there were differences between the blunt contusion and exhausted exercise models at each recovery phase. The gene expression of the autophagy-related factors was not high in the early exhaustive exercise recovery phase and subsequently followed an upward trend. But the above factors increased significantly in the immediate and early recovery phases after blunt contusion. Injury from blunt contusion may be more severe than exhaustive exercise-induced-injury, so the autophagy starts earlier according to the changes in autophagy-related factors. Level of evidence III; Therapeutic studies investigating the results of treatment.
\end{abstract}

Keywords: Contusion; Beclin1; Exercise.

\section{RESUMO}

Objetivo: Estudar os efeitos do exercício exaustivo e da contusão sobre a expressão dos fatores relacionados com a autofagia das proteínas Beclina 1, LC3 e PINK-1 no músculo esquelético de ratos. Métodos: Quarenta de dois ratos SD machos foram divididos randomicamente em 7 grupos com 6 ratos cada um: C, D0, D24, D48, E0, E24 e E48. Os ratos de cada um dos grupos foram submetidos à eutanásia e dissecados nos diferentes pontos de tempo de acordo com os grupos acima. Cada músculo quadríceps femoral dos membros posteriores esquerdos foi removido e dividido em duas partes, uma para RNAm de Beclina 1, LC3 e PINK-1 por PCR quantitativa fluorescente em tempo real e a outra para a proteína LC3 por Western blotting. Resultados: Em comparação com o grupo C, o teor de RNAm em Beclina 1, PINK-1 e LC3 no grupo exercício exaustivo imediato (EO) foi significativamente reduzido ( $p<0,01)$. Contudo, os níveis de RNAm em PINK-1 e LC3 e a proteína LC3 em células do músculo esquelético aumentaram significativamente nas 48 horas pós-depleção (E48) ( $p<0,05)$, sugerindo que a autofagia celular tendeu a aumentar durante o período de recuperação. Em comparação com o grupo C, o teor de RNAm de Beclina 1, RNAm de Pink-1 e RNAm de LC3 no grupo contusão imediata (D0) aumentou significativamente $(p<0,01)$ o que foi seguido por tendência de queda. Conclusão: Em geral, foram encontradas diferenças entre os modelos de contusão e de exercício exaustivo em cada fase de recuperação. A expressão gênica dos fatores relacionados com a autofagia não foi alta na fase de recuperação do exercício exaustivo inicial e, subsequentemente, seguiu tendência ascendente. Porém, os fatores acima aumentaram significativamente nas fases de recuperação imediata e inicial depois de contusão. O trauma contuso pode ser mais grave do que a lesão induzida por exercício exaustivo, de modo que a autofagia tem início mais cedo, de acordo com as mudanças nos fatores relacionados com a autofagia. Nível de Evidência III; Estudos terapêuticos - Investigação dos resultados do tratamento.

Descritores: Contusões; Proteína Beclina 1; Exercício Físico. 


\section{RESUMEN}

Objetivo: Estudiar los efectos del ejercicio exhaustivo y de la contusión sobre la expresión de los factores relacionados a la autofagia de las proteínas Beclina 1, LC3 y PINK-1 en el músculo esquelético de ratones. Métodos: Cuarenta y dos ratones SD machos fueron divididos aleatoriamente en 7 grupos con 6 ratones cada uno: C, DO, D24, D48, E0, E24 y E48. Los ratones de cada uno de los grupos fueron sometidos a eutanasia y disecados en los diferentes puntos de tiempo de acuerdo con los grupos encima. Cada músculo cuádriceps femoral de los miembros posteriores izquierdos fue removido y dividido en dos partes, una para RNAm de Beclina 1, LC3 y PINK-1 por PCR cuantitativa fluorescenteen tiempo real y la otra para la proteína LC3 por Western blotting. Resultados: En comparación con el grupo C, el tenor de RNAm en Beclina 1, PINK-1 y LC3 en el grupo ejercicio exhaustivo inmediato (EO) fue significativamente reducido $(p<0,01)$. Con todo, los niveles de RNAm en PINK-1 y LC3 y la proteína LCZ en células del músculo esquelético aumentaron significativamente en las 48 horas post-depleción (E48) ( $p<0,05)$, sugiriendo que la autofagia celular tendió a aumentar durante el perío do de recuperación. En comparación con el grupo C, el tenor de RNAm de Beclina 1, RNAm de Pink-1 y RNAm de LC3 en el grupo contusión inmediata (D0) aumentó significativamente $(p<0,01)$ lo que fue seguido por tendencia de caída. Conclusión: En general, fueron encontradas diferencias entre los modelos de contusión y de ejercicio exhaustivo en cada fase de recuperación. La expresión génica de los factores relacionados con la autofagia no fue alta en la fase de recuperación del ejercicio exhaustivo inicial y, subsecuentemente, siguió tendencia ascendente. Sin embrago, los factores encima aumentaron significativamente en las fases de recuperación inmediata einicial después de contusión. El trauma contuso puede ser más grave que la lesión inducida por ejercicio exhaustivo, de modo que la autofagia tiene inicio más temprano, de acuerdo con los cambios en los factores relacionados a la autofagia. Nivel de Evidencia III; Estudios terapéuticos - Investigación de los resultados del tratamiento.

Descriptores: Contusiones; Beclina-1; Ejercicio Físico.

\section{INTRODUCTION}

After skeletal muscle injury, the body will repair the damaged part. In addition to muscle satellite cells' repair, autophagy is also an important repair procedure of skeletal muscle injury. ${ }^{1,2}$ Autophagy can remove damaged cells and is an active protective measure for cells. ${ }^{3}$ Autophagy of skeletal muscle cells can transport damaged, degraded or aging proteins and organelle into the lysosome for digestion and degradation, which can provide certain energy and synthetic substrates for muscle fiber regeneration, and inhibit skeletal muscle cell apoptosis. ${ }^{4}$ The resynthesis of mitochondria and contractile proteins during the adaptation of skeletal muscle also has a certain effect on injured muscle cells. Therefore, mitochondrial autophagy of skeletal muscle has also received wide attention in the repair process of skeletal muscle injury. ${ }^{5}$

Some reports found that there were five stages of autophagy, namely the initiation, nucleation, extension, fusion, and degradation. Under the state of energy imbalance, autophagy starts and nucleates. In this process, $\mathrm{BCl}-2$ interacting protein 1 (Beclin 1 ) acts as one of the important proteins, forming the Beclin1-Bcl-2 complex regulatory pathway and affecting the extension phase of autophagy. ${ }^{6}$ Cytoplasmic microtubule-associated protein 1 light-chain3 (LC3) is a marker protein in the process of cell autophagy, mainly in the nucleation stage, and its expression level can reflect the activity of autophagy. In the PTEN induced putative kinase 1 (PINK1) / Parkin signaling pathway, PINK1 and Parkin were earlier identified proteins that regulate mitochondrial autophagy, Parkin is found in various mammalian tissues, including brain, skeletal muscle, and heart with a high expression, suggesting that PINK1 / Parkin may have a wide range of physiological effects in regulating mitochondrial autophagy.

Eccentric exhaustion exercise can lead to skeletal muscle microdamage and ultrastructural changes which has been proved by literature. Blunt trauma can cause relatively obvious muscle fiber swelling, but the dynamic changes of autophagy under the two injury models are not clear. In this paper, the authors will establish different experimental models of skeletal muscle injury to comparatively study the dynamic changes of autophagy-related factors and the autophagy levels after skeletal muscle injury.

\section{METHODS}

\section{Animals and grouping}

Male Sprague Dawley rats (aged 8 weeks, weighted 130 \pm 20 g, n =6 per group) were obtained from Comparative Medicine Centre, Jiangsu University (Jiangsu, China). Rats were breed and raised in Human Movement Science Laboratory in Yangzhou University. All animal experiments fit in the'Guide for the Care and Use of Laboratory Animals' guidelines ( $\mathrm{NIH}$ Publications no. 8023, revised 1978) and approved by the Animal Care and Use Committee of Yangzhou University for the treatment of animals (Jiangsu, China). All rats were controlled at approximately $22^{\circ} \mathrm{C}$ with a $12 / 12 \mathrm{~h}$ light-dark cycle and housed in a home cage $30 \times 41 \mathrm{~cm}$ and 25 $\mathrm{cm}$ height in a clean room. Solid diet and water were provided ad libitum. Grouping: 42 Sprague Dawley rats were randomly divided into 7 groups: (1)sedentary control ( $C, n=6)$, (2) immediately after contusion (D0, n=6), (3) 24 hours after contusion (D24, n=6), (4) 48 hours after contusion (D48, $n=6),(5)$ immediately after exhaustive exercise (E0, n=6), (6) 24 hours after exhaustive exercise(E24, n=6), (7) 48 hours after exhaustive exercise $(E 48, n=6)$. All rats were euthanized by sodium pentobarbital overdose (200 mg/kg, intraperitoneal) and killed respectively at different time points according to above groups. The rats were sampled immediately or 24 and 48 hours after exhaustive exercise and contusion respectively. The left whole quadriceps femoris of the hind limbs were taken and stored at $-80^{\circ} \mathrm{C}$, then mixed and ground the middle section of the sample for Real-time PCR and Western blotting.

\section{A single bout of exhaustive treadmill exercise}

The graded exhaustive exercise protocol was adapted by a modification of the method of Lin et al. ${ }^{8}$ The treadmill installed electric shock grid on the rear obstacle to give the animal power to exercise. In the exhaustive exercise groups, the rats were tested for 15 - 20 minutes of accommodate treadmill exercise at 10 - 30 meters / minute for 6 day. During the exercise test, they were asked to run in six lanes inclined treadmill $\left(-10^{\circ}\right)$. The treadmill speed were increased gradually to $10,15,20,25 \mathrm{~m} / \mathrm{min}$ for $10 \mathrm{~min}$ in each gear, and then accelerated to $30 \mathrm{~m} / \mathrm{min}$ until exhaustion of rats. The exhaustion standard is that 
the rats can no longer keep pace with the treadmill at the last speed 30 meters/minute, and can't stand erect when placed on the back at rest. The average exhaustion time was 105 minutes in our experiment.

\section{Contusion Injury}

The contusion injury to the rat hind-limb was produced using the mass-drop model injury first described by Kami et al ${ }^{9}$ and optimized for our laboratory. This contusion injury was moderately severe, did not result in bone injury or affect gait in the injured animals. Briefly, the technique entails dropping a $200 \mathrm{~g}$ weight of cylinder (Diameter of basal surface is $1 \mathrm{~cm}$ with $1.0 \mathrm{~J}$ of kinetic energy) from the height of $50 \mathrm{~cm}$ onto the medial surface of the left quadriceps femoris of anaesthetized rats with ethyl ether.

\section{Real-time reverse transcription-PCR}

In the present study, the mRNA expression of Beclin1, LC3 and PINK1 was assessed by real-time reverse transcription-polymerase chain reaction (RT-PCR). Using Takara SYBR Premix Ex Taq TMII for mRNA, synthesized CDNA was applied to real-time RT-PCR (ABI 9700 Thermal Cycler Dice, USA) and analyzed with 7500 Real-Time PCR System (ABI,USA). Using RNAiso Plus(Takara Bio, Japan), total RNA was extracted from the proximal portion of quadriceps femoris according to the manufacturer's instructions. Using the firststrand cDNA Synthesis kit, Samples ( 10 ng of RNA) were reverse-transcribed according to the manufacturer's protocol [PrimeScript RT Master Mix (Perfect Real Time) for mRNA, Takara Bio, Japan].

GAPDH was used as an internal standard, to normalize the amount of total RNA present in each reaction. The real-time cycle conditions were $95^{\circ} \mathrm{C}$ for $30 \mathrm{sec}$, followed by 40 cycles at $95^{\circ} \mathrm{C}$ for $5 \mathrm{sec}$, and at $60^{\circ} \mathrm{C}$ for $34 \mathrm{sec}$ for mRNA. Expression levels for each mRNA transcript were determined by normalizing each group to the sedentary group by the $2-\triangle \triangle C T$ method. Primers used for detection of rat CDNA were as follows, which were designed by Sangon Biotech (Shanghai, China).

Beclin1 forward: CGCAAGGTGGTGGCAGAGAAC reverse: AAGCATGGAGCAGCAGCACTG

LC3 forward:TCGCCGACCGCTGTAAGGAG reverse: GGTTGACCAGCAGGAAGAAGGC

PINK1 forward: FORWARD: GCCACGGTCGCACACTGTTC reverse: GCCATTGCCACCACGCTCTAC

GAPDH forward: AATGGTGAAGGTCGGTGTGAACG reverse:TCGCTCCTGGAAGATGGTGATGG

\section{Western blot analyses}

An appropriate amount of mixed quadriceps femoris were taken and shred. RIPA lysate containing PMSF(PMSF: RIPA = 100: 1, Shanghai Biyuntian Co., China) was added to the samples. After electric homogenization, the samples were sonicated and lysed at at $4^{\circ} \mathrm{C}$ overnight, then centrifuged at $12000 \mathrm{rpm}$ and $4^{\circ} \mathrm{C}$ for $30 \mathrm{~min}$. The supernatant was sub-packed. The above sample was prepared at $20 \mathrm{ug} / \mathrm{time}$, and SDS polyacrylamide gel electrophoresis was performed (electrophoresis instrument 325BR051391, BIO-RAD, USA. Separating gel concentration 12\%), then transferred to a PVDF membrane for 1 hour and blocked with 5\% skim milk. The primary antibody Anti-LC3 (Sangon Biotech Co.,China, D155238-0100, 1:500) and the internal reference AntiGAPDH (Sangon Biotech Co.,China, D1 10016-0100, 1:10000) were diluted with $5 \%$ skim milk according to the ratio of antibody instructions. Then the membrane was soaked, and incubated at $4^{\circ} \mathrm{C}$ in a three-dimensional shaker overnight. The membrane was washed 4 times and incubated the secondary antibody(Sangon Biotech Co.,1:5000) for $1 \mathrm{~h}$. Then the membrane developed by ECL (ECL Plus Ultra Sensitive Kit, Phygene Life Sci Co.,China). The target protein and GAPDH are evaluated in the same membrane. The final result was expressed as the OD ratio of the target protein LC3 to the internal reference GAPDH. Image Lab5.1 software was used to analyze the gray value.

\section{Statistical analysis}

Statistical significance was evaluated by one-way analysis of variance (ANOVA) followed by Tukey's post hoc test to correct for multiple comparisons (SPSS 21.0, SPSS Inc). Data are expressed as mean \pm standard error of mean (SEM). $P<0.05$ was considered statistically significant.

\section{RESULTS}

The results of qRT-PCR showed that compared with group $C$, the contents of Beclin1 mRNA, PINK1 mRNA, and LC3 mRNA in the immediate exhausted exercise group (E0) significantly reduced ( $p<0.01$ ). However, the levels of PINK1 mRNA, LC3 mRNA in skeletal muscle cells increased significantly in the 48 hours after exhaustion ( $E 48)(P<0.05)$. Compared with E0 group, all values in E24 and E48 significantly increased $(P<0.01)$. The whole change trend was initially low and became high afterwards. (Table 1, Figure 1)

On the other hand, compared with the $C$ group, the contents of Beclin 1 mRNA, PINK1 mRNA, and LC3 mRNA in the immediate blunt contusion group (D0) significantly increased $(p<0.01)$ and followed by a downward trend. Compared with the D0 group, D24 and D48 significantly reduced $(P<0.05)$. The whole change trend after blunt contusion was

Table 1. Genes expression in all groups at different time points after exhaustive exercise(E0,E24,E48) and contusion(D0,D24,D48).

\begin{tabular}{c|c|c|c}
\hline group(n=6) & Beclin1 mRNA & PINK1 mRNA & LC3 mRNA \\
\hline C & $1.00 \pm 0.24$ & $1.38 \pm 0.34$ & $1.03 \pm 0.14$ \\
\hline E0 & $0.13 \pm 0.07^{* *}$ & $0.10 \pm 0.05^{* *}$ & $0.12 \pm 0.04^{* *}$ \\
\hline E24 & $0.92 \pm 0.20^{\text {aa }}$ & $1.47 \pm 0.37^{\text {aa }}$ & $1.80 \pm 0.96^{\text {aa }}$ \\
\hline E48 & $1.98 \pm 0.4^{8 \mathrm{a} a}$ & $11.93 \pm 1.99^{* * a a}$ & $4.47 \pm 0.11^{* * a a}$ \\
\hline D0 & $5.20 \pm 0.53^{* *}$ & $7.18 \pm 0.56^{* *}$ & $5.83 \pm 0.79^{* *}$ \\
\hline D24 & $0.14 \pm 0.10^{* * b b}$ & $3.93 \pm 0.37^{* b}$ & $1.57 \pm 0.2^{1} b$ \\
\hline D48 & $0.17 \pm 0.16^{* * b b}$ & $2.20 \pm 0.28^{\text {b }}$ & $0.16 \pm 0.02^{* * b b}$ \\
\hline
\end{tabular}

[*]Significant difference compared with control, $\mathrm{P}<0.05$. [**] $\mathrm{P}<0.01$. [a] Significant difference compared with $E 0, P<0.05$. [aa] $P<0.01$. [b] Significant difference compared with $D 0, P<0.05$. [bb] $P<0.01 . n=6 /$ group.

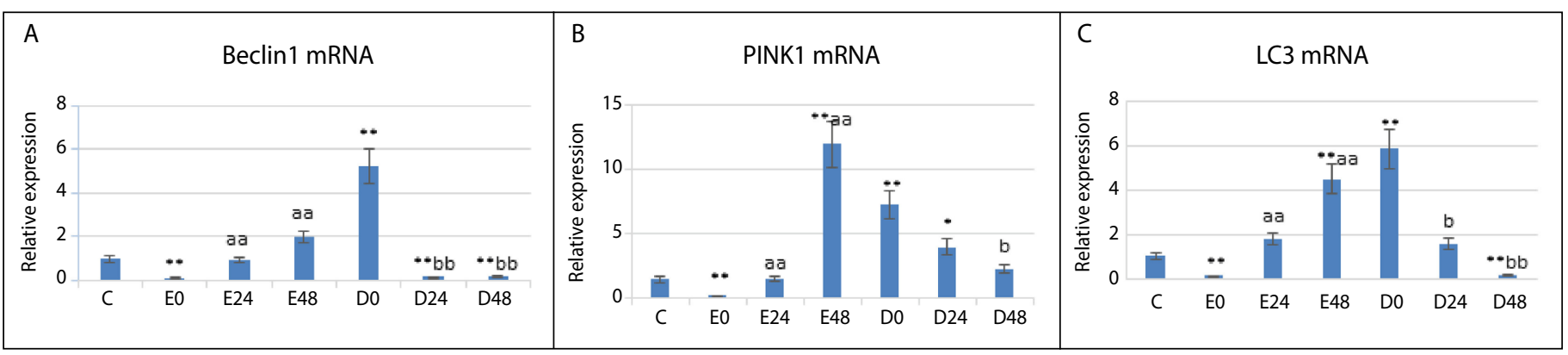

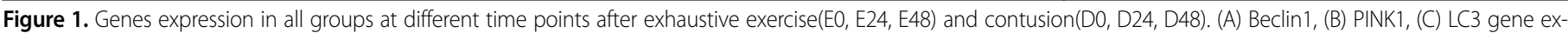

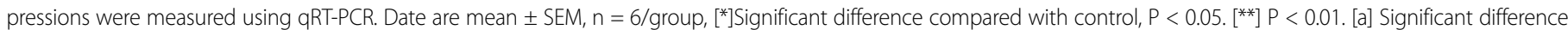
compared with E0, $P<0.05$. [aa] $P<0.01$. [b] Significant difference compared with $D 0, P<0.05$. [bb] $P<0.01$.. 
initially high and became low afterwards. Furthermore, there were differences at each recovery phase between blunt contusion and exhausted exercise models. (Table 1, Figure 1)

The results of Western blot of LC3 showed that compared with group $C$, the contents of LC3 protein of skeletal muscle in all other groups significantly increased $(P<0.05)$. Compared with $E 0$ group, the value of LC3 protein in E48 group significantly increased $(P<0.05)$. On the other side, compared with D0 group, the LC3 in D24 group was significantly increased $(P<0.01)$, then the value gradually decreased. (Figure 2 )

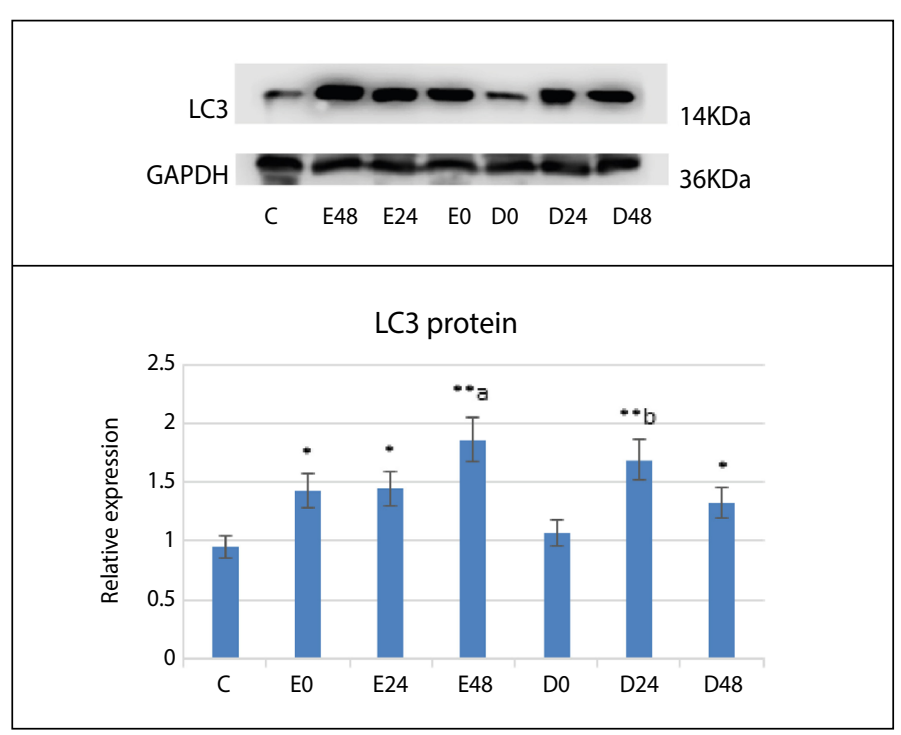

Figure 2. Protein expression of LC3 were measured by Western Blot in all groups at different time points after exhaustive exercise(E0, E24, E48) and contusion(D0, D24, D48). Date are mean $\pm S E M, n=6 /$ group, $\left.{ }^{*}\right]$ Significant difference compared with control, $\mathrm{P}<0.05$. $\left.{ }^{* *}\right] \mathrm{P}<0.01$. [a] Significant difference compared with $\mathrm{E} 0, \mathrm{P}<0.05$. [b] Significant difference compared with D0, $P<0.05$.

\section{DISCUSSION}

Eccentric exhaustion exercise can lead to skeletal muscle microdamage and ultrastructural changes which has been proved by previous studies. There also have been reports of ultrastructural changes in the previous work of our laboratory. Blunt trauma can cause relatively obvious muscle fiber swelling, but the dynamic changes of autophagy under the two injury models are not clear, which has motivated this study. Through synchronous comparison, the difference and degree of the autophagy in two models will be explored and evaluated.

\section{Effects of exercise training on autophagy-related factors}

There were rarely reports investigating the autophagy-related factors under the models of exhaustive exercise and contusion. The former reports showed that high-intensity interval training (HIIT) was more effective for improving exercise performance than continuous moderate-intensity training (CMT) and this improvement is related to basal autophagic adaptation and mitochondria function in cardiac and skeletal muscle. The results indicated that the expression of Beclin-1, Bnip3, P62, ATG-3, LC3-II and LC3II/LC3-1 ratio was significantly increased only in soleus and cardiac muscle following HIIT. ${ }^{10,11}$ In another rat model, the LC3II/LC3 ratio was decreased significantly by a single bout of exercise. But autophagy-related protein changes were not found in the white (glycolytic) gastrocnemius. ${ }^{12}$ In our graded exhaustive exercise protocol, LC3 mRNA and protein expression of mixed quadriceps femoris in each phase are not completely synchronized. At 48 hours after exhaustive exercise, both were significantly increased. But LC3 protein increased steadily after exhaustion immediately, while LC3 mRNA decreased immediately after exhaustion and then increased. It may be due to more consumption and damage of LC3 mRNA immediately after exhaustion.
Some previous reports investigated the time-dependent expressions of autophagy-related factors. The results suggest that a single bout of $50 \mathrm{~min}$ treadmill exercise attenuates the autophagic response in murine skeletal muscle. The autophagy marker LC3-II, LAMP2a, Atg7, and Beclin-1 in murine gastrocnemius muscle was significantly decreased during the recovery period $(3,6$, and $12 \mathrm{~h}$ ) whereas there was no decrease immediately after exercise $(0 \mathrm{~h}) .^{13}$ In another report, the autophagic markers LC3B-II of the quadriceps femoris increased at 120 min of running and exhaustion (T-e), but p62 significantly decreased at T-e. The data suggested that mitochondrial fusion was unchanged, but mitochondrial fission is quickly increased during exercise. ${ }^{14}$

In our rat models with different phases, we found that the contents of Beclin1 mRNA, PINK1 mRNA, and LC3 mRNA in the immediate exhausted exercise group (E0) significantly reduced by compared with group C, indicating that the level of cellular autophagy were not high at the early recovery phase of exhausted exercise. But the levels of PINK1 mRNA, LC3 $m R N A$, and LC3 protein in quadriceps femoris increased significantly in the 48 hours after exhaustion ( E48), suggesting that cell autophagy had an increasing trend during the recovery period.

On the other hand, late exercise preconditioning (LEP) is confirmed to have a protective effect on acute cardiovascular stress. ${ }^{15}$ LEP caused mitochondrial degradation in a Parkin-mediated manner, and suppressed significantly injuries exhausted exercise-induced by increasing the efficiency of LC3-outer mitochondrial membrane translocation. Bnip3 may play a role in inducing mitochondrial LC3-II increases. ${ }^{16}$ In a previous study, ${ }_{1}^{17}$ eight men took part in ultraendurance exercise for a 200-km running race. The transcript levels of autophagy-related genes LC3b, BNIP3, ATG4b and ATG12 in human skeletal muscle markedly increased, which activated the autophagy. The other reports indicated that autophagy regulatory events were attenuated in old skeletal muscle. But the level of autophagy can be upregulated by some exercise training. ${ }^{18,19}$

\section{Effects of diseases and muscle injury on autophagy-related factors}

There were also rarely reports investigating the autophagy-related factors under the models of contusion. The recent study showed that markers of mitochondrial fission were elevated while fusion proteins were reduced following a sciatic nerve transection. ${ }^{20}$ There were elevations in total expression of the mitophagy markers Beclin1, PINK1, LC3-II, p62 and phosphorylated ULK1(S555). As a result, paralysis of the gastrocnemius leads to a progressive elevation in expression of mitophagic proteins and mitochondrial fission. Rehabilitative or pharmaceutical interventions to limit excess mitophagy may be effective therapies to protect paralyzed muscle mass and function.

In terms of CKD-induced muscle atrophy, ${ }^{21}$ chronic kidney disease (CKD) was associated with activated autophagy and mitophagy accompanied by the elevated proteins and mRNAs expression of PINK1, BNIP3, LC3, p62 and PARKIN in the skeletal muscle and isolated mitochondria. The autophagy may be activated by $\mathrm{FOXO} 3$ translational factors in the skeletal muscle, which maybe a new way of intervention for CKD muscle atrophy. ${ }^{22}$ In addition, regular aerobic exercise can effectively influence several autophagy-related factors in skeletal muscle of hypertensive and normotensive rats. ${ }^{23}$

About acute contusion repair of skeletal muscle, ${ }^{24}$ the report indicated that the expressions of P62 and LC3-II were initially high and became low afterwards. Compared with the control group and the $14 \mathrm{~d}$ group, the expression of LC3-II and P62 were significantly increased after acute contusion of skeletal muscle in the $3 \mathrm{~d}, 5 \mathrm{~d}, 7 \mathrm{~d}$. It showed that the rate of injury repair may be related to the autophagy level.

Our contusion model was not similar to previous reports regarding recovery phases, we found that the contents of Beclin1 mRNA, PINK1 mRNA, and LC3 mRNA in the immediate blunt contusion group (D0) significantly increased by compared with the $\mathrm{C}$ group, indicating that 
the cell autophagy level significantly increased at immediate and early recovery phases after the blunt contusion followed by a downward trend. To our knowledge, this is the first comparative study investigating the autophagy-related factors through two models of one-time exhaustive exercise and contusion. In conclusion, our rat models showed differences at each recovery phase between blunt contusion and exhausted exercise models. Blunt contusion were more severe than exhausted exercise injury, so the autophagy started earlier according to the changes of autophagy-related factors. LC3 mRNA has been significantly increased immediately after the blunt injury, but LC3 protein increased significantly in 24 hours after exhaustion with a lag, and then both decreased.

\section{PINK1/Parkin signaling pathway and mitophagy}

In the regulatory mechanism of mitophagy, the accumulation of PINK1 in the outer membrane can recruit and phosphorylate Parkin to localize at mitochondria, which strengthens its E3 ubiquitin ligase activity. Parkin can make P62 accumulate on mitochondrial matrix proteins and bind LC3, then promotes target mitochondria to enter autophagosomes and initiates mitochondrial autophagy. ${ }^{25,26}$

Current models of selective autophagy indicate that autophagy receptors, including NDP52 and Optineurin, can link cargo to autophagosomal membranes. ${ }^{3}$ The LC3 interacting region (LIR) motif within autophagy receptors is widely recognized as being essential for selective sequestration of cargo. This is thought to occur via autophagy receptor binding to Atg8 homologs (LC3/GABARAPs) through an LC3 interacting region (LIR). Here the LIR motif within NDP52 and optineurin is dispensable for Atg8 selectivity and recruitment during PINK1/Parkin mitophagy.

Generally, damaged organelles and protein aggregates are marked with ubiquitin chains to trigger autophagy. ${ }^{27}$ To activate the ubiquitin ligase Parkin, the ubiquitin kinase PINK1 phosphorylates ubiquitin to initiate mitophagy, which build ubiquitin chains on mitochondrial outer membrane proteins and recruit autophagy receptors. In our rat models, the changes PINK1 mRNA, Beclin1 mRNA, and LC3 mRNA were basically similar. Furthermore, the regulatory mechanism of PINK1/Parkin signaling pathway during muscle injury and regeneration under our two models needs to be investigated in the future.

\section{CONCLUSIONS}

Generally, there were differences at each recovery phase between blunt contusion and exhausted exercise models. The genes expression of the autophagy-related factors Beclin1, PINK1, and LC3 were not high at the early recovery phase of exhausted exercise followed by an upward trend. But above factors increased significantly at immediate and early recovery phases after the blunt contusion. Blunt contusion may be more severe than exhausted exercise injury, so the autophagy starts earlier according to the changes of autophagy-related factors.

All authors declare no potential conflict of interest related to this article

AUTHORS' CONTRIBUTIONS: Each author made significant individual contributions to this manuscript. TP and MJ conceived and designed the experiments. TP and MJ performed the experiments. MJ analyzed the data. JJ, FY, CQ and TY contributed reagents/materials/analysis tools. Tongbin Pan wrote the manuscript. All authors read and approved the manuscript.

\section{REFERENCES}

1. Russ DW, Garvey SM, Densmore C, Hawksa T, Hermana S, Pardia K. Effect of acute muscle contusion injury, with and without dietary fish oil, on adult and aged male rats: contractile and biochemical responses. Exp Gerontol. 2018;111:241-52.

2. Vainshtein A, Tryon LD, Pauly M, Hood DA. Role of PGC-1 a during acute exercise-induced autophagy and mitophagy in skeletal muscle. Amer J Physiol Cell Physiol. 2015;308(9):710-9.

3. Baechler BL, Bloemberg D, Quadrilatero J. Mitophagy regulates mitochondrial network signaling, oxidative stress, and apoptosis during myoblast differentiation. Autophagy. 2019;15(9):1606-19.

4. Karim MR, Kawanago H, Kadowaki M. A quick signal of starvation induced autophagy: Transcription versus post-translational modification of LC3. Anal Biochem. 2014;465:28-34.

5. Padman BS, Nguyen TN, Uoselis L, Skulsuppaisarn M, Nguyen LK, Lazarou M, et al. LC3/GABARAPs drive ubiquitin-independent recruitment of Optineurin and NDP52 to amplify mitophagy. Nat Commun. 2019;10:408.

6. Fava LL, Rainer J, Haschka MD, Geley S, Villunger A. Beclin 1 is dispensable for chromosome congression and proper outer kinetochore assembly. EMBO Rep. 2015;16(10):1233-6.

7. Pickrell AM, Youle RJ. The role of PINK1, parkin, and mitochondrial fidelity in Parkinson's disease. Neuron. 2015;85(2):257-73

8. 8. LinWT, Yang SC, Tsai SC, Huang CC, Lee NY. L-Arginine attenuates xanthine oxidase and myeloperoxidase activities in hearts of rats during exhaustive exercise. Br J Nutr. 2006;95:67-75.

9. Kami K, Masuhara M, Kashiba H, Kawai Y, Noguchi K. Changes of vinculin and extracellular matrix components following blunt trauma to rat skeletal muscle. Med Sci Sports Exerc. 1993;25(7):832-4.

10. Li FH, Li T, Su YM, Ai JY, Duan R, Liu TCY, et al. Cardiac basal autophagic activity and increased exercise capacity. J Physiol Sci. 2018;68(6):729-42.

11. Li FH, Li T, Ai JY, Sun L, Min Z, Duan R, et al. Beneficial autophagic activities, mitochondrial function, and metabolic phenotype adaptations promoted by high-Intensity Interval training in a rat model. Front Physiol. 2018;9:571.

12. Zhang DD, Lee JH, Kwak SE, Shin HE, Zhang YJ, Moon HY, et al. Effect of a single bout of exercise on autophagy regulation in skeletal muscle of high-fat high-sucrose diet-fed mice. J Obes Metab Syndr. 2019;28(3):175-85.

13. Kim YA, Kim YS, Song W. Autophagic response to a single bout of moderate exercise in murine skeletal muscle. J Physiol Biochem. 2012;68(2):229-35.

14. Pagano AF, Py G, Bernardi H, Candau RB, Sanchez AMJ. Autophagy and Protein Turnover Signaling in Slow-Twitch Muscle during Exercise. Med Sci Sports Exer. 2014;46(7):1314-25
15. Yuan Y, Pan SS. Parkin mediates mitophagy to participate in cardioprotection induced by late exercise preconditioning but Bnip3 does not. J Cardiovasc Pharmacol. 2018;71(5):303-16.

16. Yuan Y, Pan SS, Wan DF, Lu J, Huang Y. H2O2 Signaling-Triggered PI3K Mediates Mitochondrial Protection to Participate in Early Cardioprotection by Exercise Preconditioning. Oxid Med Cell Longev. 2018:1916841.

17. Jamart C, Benoit N, Raymackers JM, Kim HJ, Kim CK, Francaux M. Autophagy-related and autophagy-regulatory genes are induced in human muscle after ultraendurance exercise. Eur J Appl Physiol. 2012;112(8):3173-7

18. Mejias-Pena Y, Rodriguez-Miguelez P, Fernandez-Gonzalo R, Martinez-Florez S, Almar M, Paz JÁ, et al. Effects of aerobic training on markers of autophagy in the elderly. 2016;38(2):33.

19. Kim YA, Kim YS, Oh SL, Kim HJ, Song W. Autophagic response to exercise training in skeletal muscle with age. J Physiol Biochem. 2013;69(4):697-705.

20. Graham ZA, Harlow L, Bauman WA, Cardozo CP. Alterations in mitochondrial fission, fusion, and mitophagic protein expression in the gastrocnemius of mice after a sciatic nerve transection. Muscle \& Nerve. 2018;58(4):592-9.

21. Zhang YY, Gu L, Huang J, Cai MC, Yu HL, Zhang W, et al. CKD autophagy activation and skeletal muscle atrophy-a preliminary study of mitophagy and inflammation. Eur J Clin Nutr. 2019;73(6):950-60.

22. Su Z, Klein JD, Du J, Franch HA, Zhang LP, Hassounah F, et al. Chronic kidney disease induces autophagy leading to dysfunction of mitochondria in skeletal muscle. Amer J Physiol-Renal Physiol. 2017;312(6):F1128-40.

23. McMillan EM, Pare MF, Baechler BL, Graham DA, Rush JWE, Quadrilatero J, et al. Autophagic signaling and proteolytic enzyme activity in cardiac and skeletal muscle of spontaneously hypertensive rats following chronic aerobic exercise. PLOS ONE. 2015;10(3): e0119382.

24. Luo A, Tang CL, Huang SQ, Zhao DD, Zhang AN, Guo QH, et al. Changes in expression of autophagy-related factors during acute contusion repair of skeletal muscle. Chinese J Appl Physio. 2018;34(2):97-101.

25. Thomas MD, Edward AF. The three'P's of mitophagy: PARKIN, PINK1, and post-translational modifications, Genes \& Dev. 2015;29(10):989-99.

26. Burman JL, Pickles S, Wang C, Sekine S, Vargas JNS, Zhang Z, et al. Mitochondrial fission facilitates the selective mitophagy of protein aggregates. J Cell Biol. 2017;216(10):3231-47.

27. Lazarou M, Sliter DA, Kane LA, Sarraf SA, Wang CX, Burman JL, et al. The ubiquitin kinase PINK1 recruits autophagy receptors to induce mitophagy. Nature. 2015;524(7565):309-14. 